\title{
The Effectiveness of Autohemotherapy in Chronic Urticaria Treatment in the Dr. Mohammad Hoesin General Hospital and Pertamina Hospital Palembang
}

\author{
Nopriyati Husan, Sarah Diba Zulkarnain, Athuf Thaha, Maria Mayfinna Gozali, Tiar \\ Marina Octyvani \\ Department of Dermatology and Venereology, Faculty of Medicine Universitas Sriwijaya/Dr. \\ Mohammad Hoesin General Hospital, Palembang, Indonesia
}

\begin{abstract}
Background: Chronic urticaria $(\mathrm{CU})$ is one of the most common case found in dermatology and venereology and it decreases the quality of life. Autohemotherapy (AHT) is an innovative therapy that works by desensitization and activation of the local immune system, and it is effective for recurrent or refractory urticaria. AHT technique is simple, inexpensive, and does not require special expertise that can be done at all levels of health services in Indonesia. Purpose: to determine the effectiveness of AHT in the CU treatment. Methods: This was a clinical trial research with involving patients with CU in the AllergoImmunology Clinic of Department of Dermatology and Venereology Dr. Mohammad Hoesin General Hospital (DV RSMH) and Pertamina Hospital Palembang. The Urticaria Activity Score (UAS7) and Dermatology Life Quality Index (DLQI) assessments were carried out on week 1 and week 10. Result: The research was conducted from 1 July - 30 September 2019 involving 72 eligible patients with 2 dropouts (2.8\%). The mean age was 47 years (15-72 years), with 46 (63.9\%) are women. Chronic spontaneous urticaria (CSU) was the most frequent diagnosis observed in 64 people $(88.9 \%)$. Adverse events included bruises at the injection site $(\mathrm{n}=1 ; 1.4 \%)$ and at the blood draw location $(\mathrm{n}=1 ; 1.4 \%)$. On week 1, mean UAS7 was $30.77 \pm 2.46$, mean DLQI $21.66 \pm 3.60$. By week 10, UAS7 and DLQI significantly decrease to $4.12 \pm 2.89$ and $2.51 \pm 1.53(\mathrm{p}<0.005)$. Conclusion: There was a significant decrease in UAS7 and DLQI in chronic urticaria patients after receiving AHT therapy for 10 weeks. This research concluded AHT can serve as an option in chronic urticaria treatment.
\end{abstract}

Keywords: autohemotherapy, chronic urticaria, urticaria activity score, dermatology life quality index.

Correspondence: Nopriyati, Department of Dermatology and Venereology, Faculty of Medicine Universitas Sriwijaya / Dr. Moh. Hoesin General Hospital, Jendral Sudirman Km.3,5 Street, Palembang, Indonesia. Phone: +62711314172 , e-mail: nopriyatihusan@gmail.com.

\section{BACKGROUND}

Autohemotherapy (AHT) is an immunotherapy by injecting whole blood in a certain amount. Treatment with blood transfusions, which was popular before antibiotics discovery, is a therapeutic procedure for various diseases. The autohemotherapy desensitization method was carried out by Ravaut in 1913. This has been used in the pruriginosa and blistering diseases treatment and has been recommended as a treatment for urticaria. The mechanism of autohemotherapy in urticaria is not clear yet. Ravaut stated the therapy is useful to restore the disturbed immunological balance by suppressing abnormal reactions, making the body to return to its normal sensitivity. ${ }^{1}$

The first-line treatment of urticaria is antihistamine $(\mathrm{AH})$, but not all patients respond satisfactorily. ${ }^{2}$ European Academy of Allergy and Clinical Imnnunology (EAACI) in 2018 recommended the $2^{\text {nd }}$ generation of antihistamine 1 (AH1) to avoid the effects of sedation and psychomotor retardation due to the administration of the first generation $\mathrm{AH} 1 .^{3} \mathrm{AH}$ can reduce itching, shorten the duration of urticas and reduce the amount of urticas although they do not eliminate them completely; there are side effects on increasing the dose and still cause recurrence. ${ }^{4}$

Autohemotherapy is one of alternative therapy for autoimmune and allergic disease in dermatology, including pruriginous dermatitis, psoriasis vulgaris, and vesicobullous diseases. Autohemotherapy has been proposed as a therapeutic intervention for the treatment of chronic urticaria (CU). ${ }^{5-7}$ AHT technique is simple, inexpensive, and does not require special expertise, can be done at all levels of health services in Indonesia. However, there are conflicting results regarding the effectiveness of autohemotherapy. ${ }^{8}$

Dr. Mohammad Hoesin General Hospital (RSMH) Palembang is a national referral hospital in South Sumatera, and it is the main teaching hospital of the Faculty of Medicine, Universitas Sriwijaya. We were motivated because there has been no evaluation of AHT in CU treatment in Palembang. The purpose of this study was to determine the effectiveness of AHT 
in the treatment of chronic urticaria and the adverse event of AHT.

\section{METHODS}

This was a clinical trial research. The study was conducted at the Allergy-Immunology DV RSMH and Pertamina Hospital Palembang from 1 July - 30 September 2019. The research participants were all patients with chronic urticaria admitted to the AllergoImmunology Clinic of Department of Dermatology and Venereology (DV) RSMH and Pertamina Hospital Palembang from July-September 2019. The inclusion criteria were patients with unsuccessful first-line therapy, older than 16 years old, and willing to sign informed consent. All type of chronic urticaria such as physical urticaria, cholinergic urticaria, urticaria solaris, food allergy urticaria, dermatographism, chronic spontaneous urticaria were included. The exclusion criteria were patients prescribed with bloodthinning drugs, hypercoagulated blood conditions and were unwilling to participate in this study. The participant's status, Urticaria Activity Score (UAS7) and Dermatology Life Quality Index (DLQI) were recorded at week 1 and week10. UAS7 has 5 categories: itch and hive free (score 0); well-controlled urticaria (score 1-6); mild urticaria (score 7-15); moderate activity urticaria (score 16-27); and severe activity (score 28-42). DLQI has 5 categories: no effect at all (0-1); small effect (score 2-5), moderate effect (score 5-10), very large effect (score 11-20), and extremely large effect on patient's life (21-30). The collected data were analyzed with SPSS 22.0 software. This study was approved by the committee of ethics of the Faculty of Medicine Universitas Sriwijaya, Palembang.

\section{RESULT}

The mean participants' age was 47 . The youngest patient was 18 years old, and the oldest was 78 years old. There were 22 patients $(30 \%)$ in the $48-57$ years age group and 15 patients $(20 \%)$ in the $28-37$ years age group. The research participants consisted of 46 female patients $(63.9 \%)$ and 26 male patients $(36.1 \%)$. The research participants consisted of 26 housewives (36.1\%), 20 unemployed persons (27.8\%), 6 students ( $8.3 \%$ ). The patients' medical records showed that there were 64 patients $(88.9 \%)$ diagnosed with chronic spontaneous urticaria, with the remaining physical urticaria $(2.8 \%)$, cholinergic urticaria $(2.8 \%)$, chronic urticaria $(2.8 \%)$, urticaria food allergy $(1.4 \%)$, and dermatographism (1.4\%).

The mean of week 1 UAS7 scores was $30.77 \pm$ 2.46 and the score range was 27-39 with a median of 30. The mean of week 10 UAS7 score was $4.12 \pm 2.89$ and the score range was $0-9$. The mean of week 1 DLQI scores was $21.66 \pm 3.60$ and the score range was $15-29$, with a median of 21 . The mean of week 10 DLQI scores was $2.51 \pm 1.53$ with the score range was 0-6.

Table 1. Week 1 and week 10 Urticaria activity score (UAS7) \& Dermatology Life Quality Index (DLQI).

\begin{tabular}{lccc}
\hline Parameter & Mean \pm SD & Median & Score Range \\
\hline Urticaria Activity Score (UAS7) on week 1 & $30.77 \pm 2.46$ & 30 & $27-39$ \\
Urticaria Activity Score (UAS7) on week 10 & $4.12 \pm 2.89$ & 4 & $0-9$ \\
\hline $\begin{array}{l}\text { Dermatology Life Quality Index (DLQI) on week } \\
1\end{array}$ & $21.66 \pm 3.60$ & 21 & $15-29$ \\
$\begin{array}{l}\text { Dermatology Life Quality Index (DLQI) on } \\
\text { week-10 }\end{array}$ & $2.51 \pm 1.53$ & 2 & $0-6$ \\
\hline
\end{tabular}

$\mathrm{SD}=$ Standard deviation

The UAS7 results on week 1 showed 69 patients $(95.8 \%)$ has severe activity urticaria. On week 10,43 patients $(59.7 \%)$ had well-controlled urticaria, and 19 patients $(26.4 \%$ ) had mild urticaria (Table 2 ). The DLQI results on week 1 showed the most patients $(62.5 \%)$ had scores stratified under significant effect. On week 10, the number dropped to none $(0 \%)$ (Table 2 , picture 1 and 2).

The results of normality tests for UAS7 and DLQI on baseline and week 10 found that baseline ( $p$ value $=$ $0.002)$ and week-10 UAS7 ( $p$ value $=0.001)$ were not normally distributed $(\mathrm{p}$ value $=0.061)$ and the DLQI baseline was normally distributed while at week 10 it was not normally distributed ( $\mathrm{p}$ value $=0.002$ ).

Chi-square test result showed that there was no relationship between patients' demography (age, sex, occupation, diagnosis) and UAS7; age ( $p$ value = $0.156)$, gender $(\mathrm{p}$ value $=0.385)$, occupation $(\mathrm{p}$ value $=$ $0.124)$, main diagnosis $(\mathrm{p}$ value $=0.897)$ with an alpha value of $5 \%(0.05) \mathrm{p}>\alpha$.

Also the chi-square test result showed that there was no relationship between patients' demography (age, sex, occupation, diagnosis) and DLQI; age ( $p$ value $=0.633)$, gender $(p$ value $=0.319)$, occupation $(p$ 
value $=0.616)$, diagnosis $(\mathrm{p}$ value $=0.939)$ with alpha value $5 \%(0.05) \mathrm{p}>\alpha$.

The mean of week 1 UAS7 was $30.77 \pm 2.46$ and the mean of week 10 UAS7 was $4.12 \pm 2.89$. Statistical test using Wilcoxon test results showed that there were differences between week 1 UAS7 and week 10 UAS7 ( $\mathrm{p}$ value $=0.000) \mathrm{p}<\alpha$. This suggested that autohemotherapy was effective in reducing UAS7.

The mean of week 1 DLQI was $21.66 \pm 3.60$ and the mean of week 10 DLQI was $2.51 \pm 1.53$. Statistical test using Wilcoxon test results showed that there were differences between week 1 DLQI and week 10 DLQI ( $\mathrm{p}$ value $=0.000) \mathrm{p}<\alpha$. This suggested that autohemotherapy was effective in reducing DLQI.

The data of follow-up events found that only 2 patients $(2.8 \%)$ had bruise at the location where blood was collected, 1 patient (1.4\%) had bruising at the blood injection site, 1 patient had an increase in body temperature (1.4\%) and $14(19.4 \%)$ people had flares on 5 th-6th week.

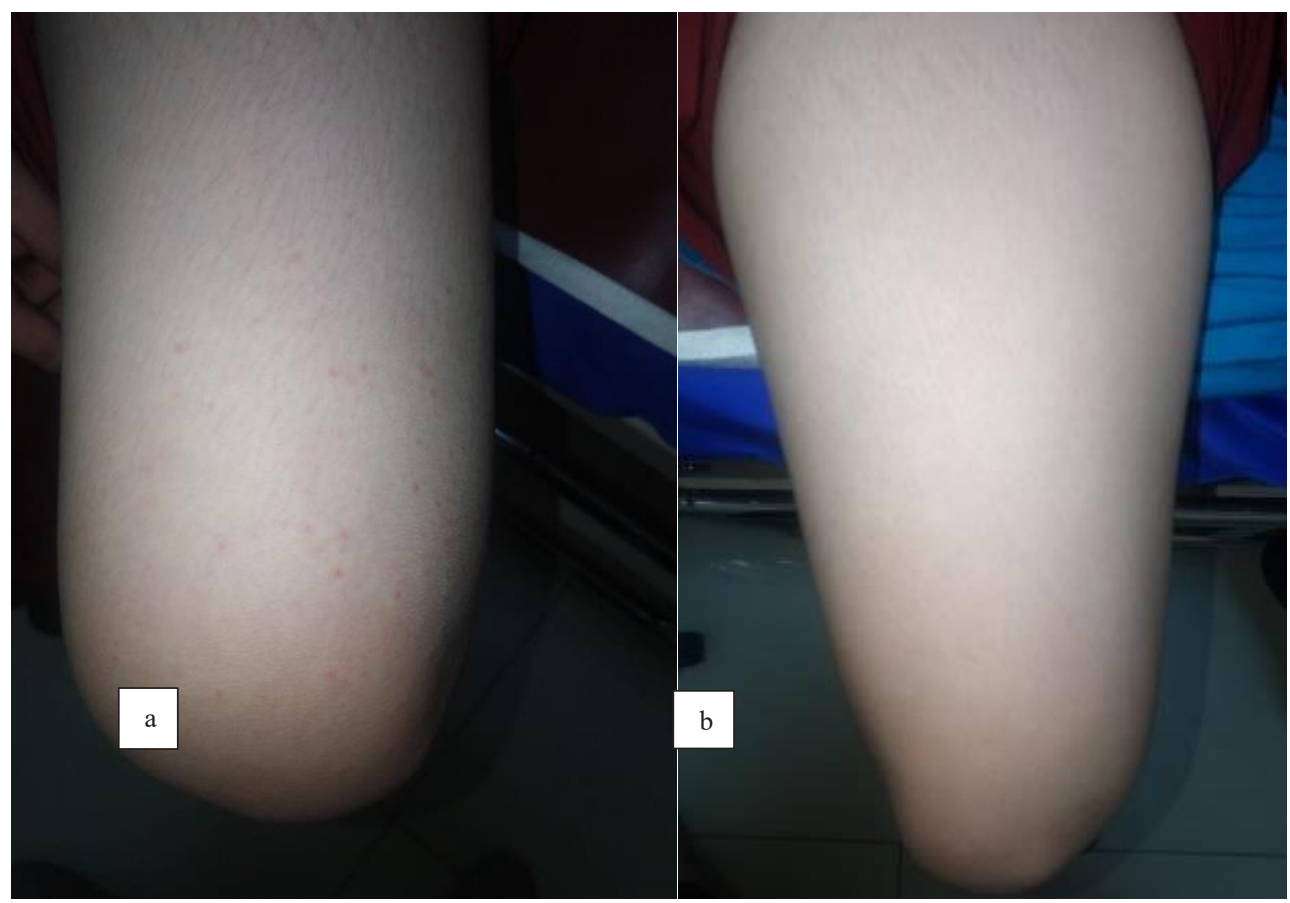

Picture 1. Patient 1. (a) baseline. (b) week-10.

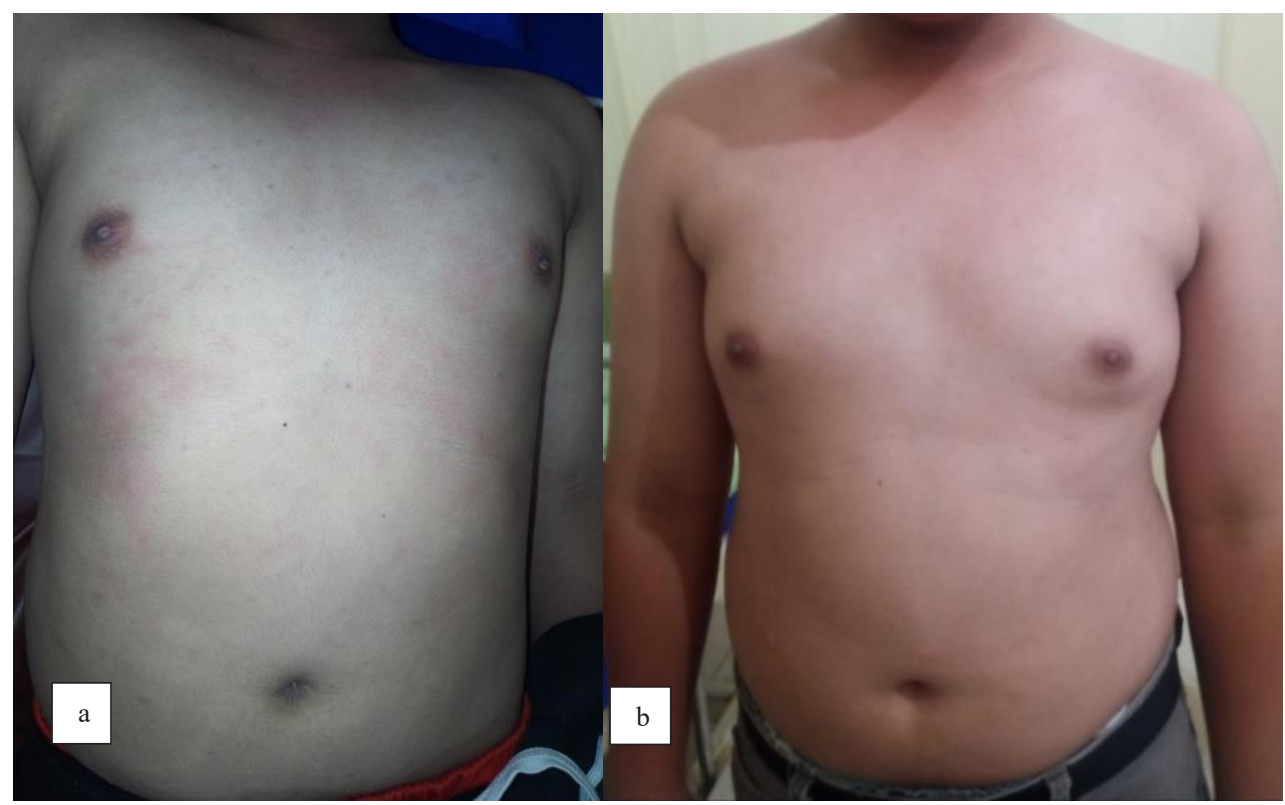

Picture 2. Patient 2. (a) baseline. (b) week-10. 
Table 2. Frequency distribution based on Urticaria Activity score (UAS7) and Dermatology Life Quality Index (DLQI).

\begin{tabular}{|c|c|c|c|}
\hline \multicolumn{2}{|c|}{ Urticaria } & $\mathrm{n}$ & $\%$ \\
\hline \multicolumn{4}{|c|}{ Urticaria Activity Score (UAS7) on week 1} \\
\hline - & itch and hive free $(0)$ & 0 & 0 \\
\hline - & well-controlled urticaria (1-6) & 0 & 0 \\
\hline - & mild urticaria (7-15) & 0 & 0 \\
\hline - & moderate activity urticaria (16-27) & 3 & 4.2 \\
\hline - & severe activity urticaria $(28-42)$ & 69 & 95.8 \\
\hline \multicolumn{4}{|c|}{ Urticaria Activity Score (UAS7) on week 10} \\
\hline - & itch and hive free $(0)$ & 10 & 13.9 \\
\hline- & well-controlled urticaria (1-6) & 43 & 59.7 \\
\hline - & mild urticaria (7-15) & 19 & 26.4 \\
\hline - & moderate activity urticaria (16-27) & 0 & 0 \\
\hline - & severe activity urticaria $(28-42)$ & 0 & 0 \\
\hline \multicolumn{4}{|c|}{ Dermatology Life Quality Index (DLQI) on week 1} \\
\hline - & No effect at all on patient's life $(0-1)$ & 0 & 0 \\
\hline- & Small effect on patient's life (2-5) & 0 & 0 \\
\hline - & Moderate effect on patient's life (5-10) & 27 & 37.5 \\
\hline- & Very large effect on patient's life (11-20) & 45 & 62.5 \\
\hline- & Extremely large effect on patient's life (21-30) & 0 & 0 \\
\hline \multicolumn{2}{|c|}{ Dermatology Life Quality Index (DLQI) on week 10} & 0 & 0 \\
\hline- & No effect at all on patient's life $(0-1)$ & 23 & 31.9 \\
\hline - & Small effect on patient's life (2-5) & 44 & 61.1 \\
\hline - & Moderate effect on patient's life (5-10) & 5 & 6.9 \\
\hline- & Very large effect on patient's life (11-20) & 0 & 0 \\
\hline - & Extremely large effect on patient's life (21-30) & 0 & 0 \\
\hline
\end{tabular}

Table 5. Differences in baseline and week-10 Urticaria Activity Score (UAS7) and Dermatology Life Quality Index (DLQI).

\begin{tabular}{lccccc}
\hline Assessement & $\mathrm{n}$ & $\begin{array}{c}\text { Mean } \\
\overline{\mathrm{x}} \pm \mathrm{SD}\end{array}$ & Median & Min - Max & $\mathrm{p}$ value \\
\cline { 1 - 5 } Week 1 UAS7 & 72 & $30.777 \pm 2,46$ & 30 & $27-39$ & 0.000 \\
\hline Week 10 UAS7 & 72 & $4.125 \pm 2,89$ & 4 & $0-9$ & \\
\hline Week 1 DLQI & 72 & $21.66 \pm 3,60$ & 21 & $15-29$ & 0.000 \\
\hline Week-10 DLQI & 72 & $2.51 \pm 1,53$ & 2 & $0-6$ & \\
\hline
\end{tabular}

\section{Wilcoxon test}

SD: Standar Deviasi; UAS: Urticaria activity score; DLQI: Dermatology life quality index

Tabel 6. Frequency distribution by adverse events.

\begin{tabular}{lcc}
\hline Adverse event & Participant (n) & Percentage (\%) \\
\hline Bruise in injection site & & \\
\hline$-\quad$ No & 71 & 98.6 \\
$-\quad$ Yes & 1 & 1.4 \\
\hline Bruise in blood draw site & & \\
\hline$-\quad$ No & 70 & 97.2 \\
$-\quad$ Yes & 2 & 2.8 \\
\hline Rised temperature & & \\
$-\quad$ No & 71 & 98.6 \\
$-\quad$ Yes & 1 & 1.4 \\
\hline Flare at week 5-6 & & 80.6 \\
\hline$-\quad$ No & 58 & 19.4 \\
$-\quad$ Yes & 14 &
\end{tabular}




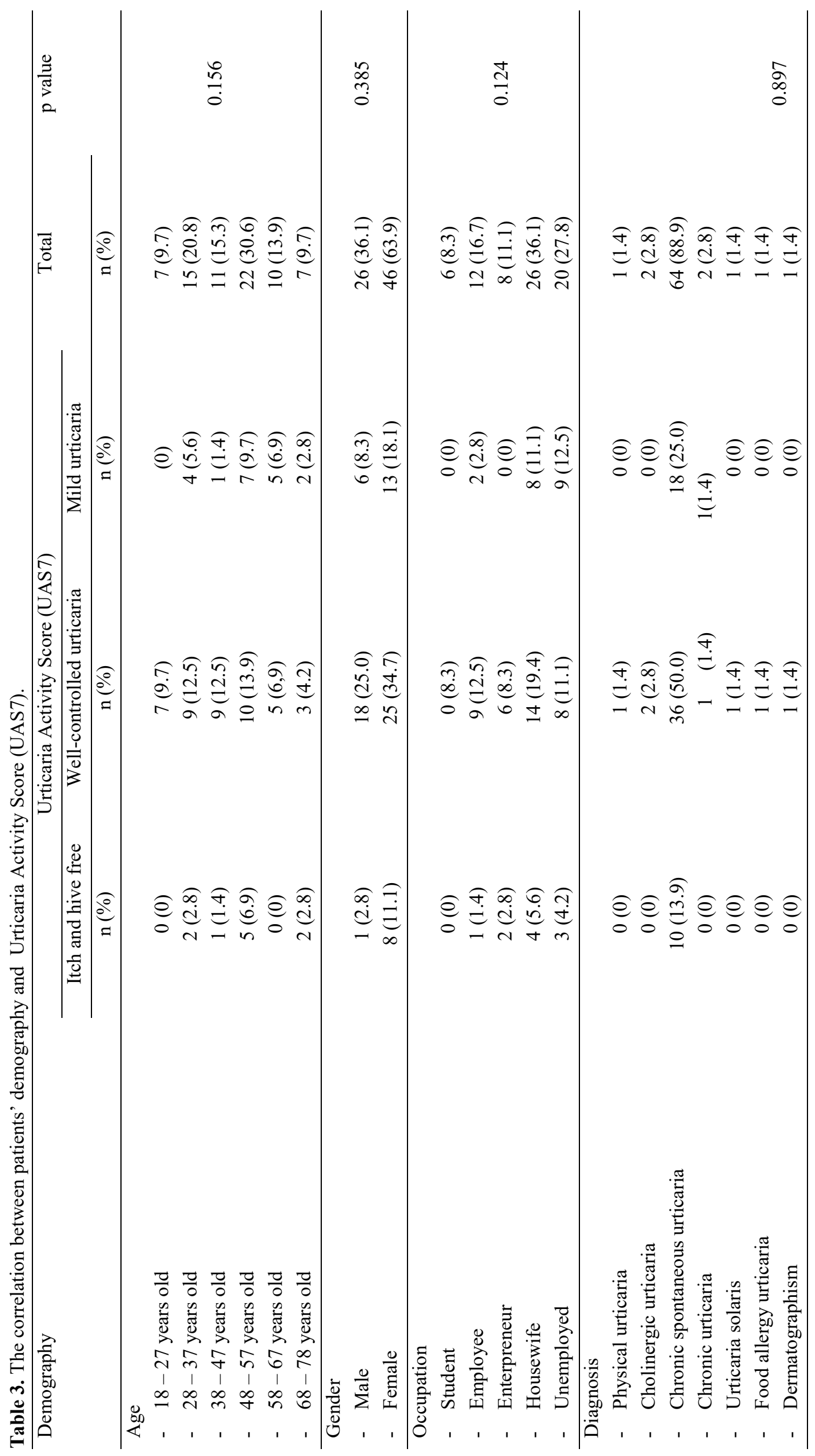




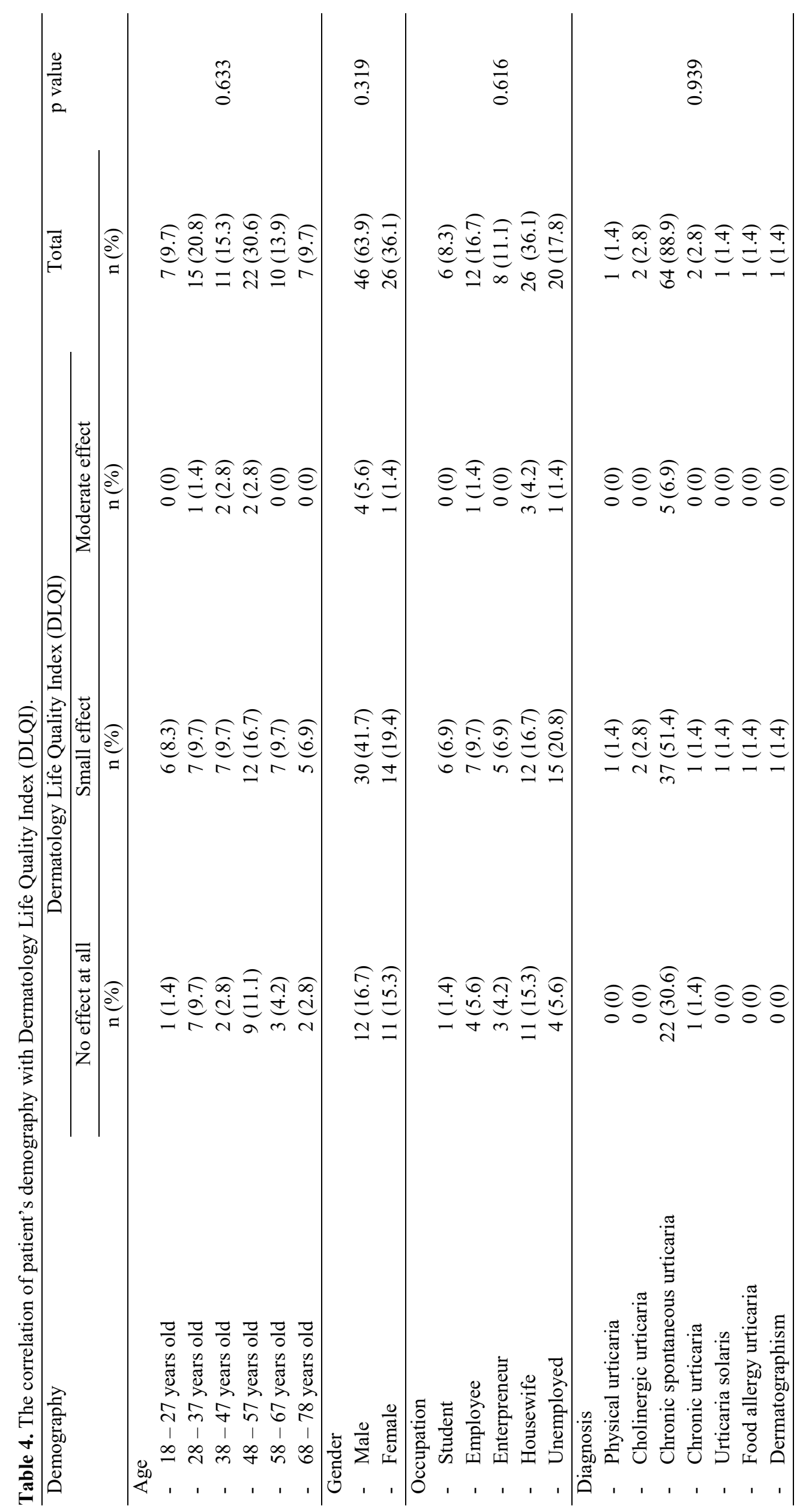




\section{DISCUSSION}

There were 72 eligible participants and 2 dropouts. The 2 participants dropout because one of them had satisfactory result and the other because of the far distance of home from the hospital. The mean of patients' age was 47 , and there were more female than male patients. This was in line with a research by Nopriyati et al. (2010). The research reported that the most CU patients were females and the highest age group was $45-49$ years. ${ }^{9}$

On week 1, the highest UAS7 category was severe activity urticaria $(95.8 \%)$. However, on week 10 there was some decrease in well-controlled urticaria $(59.7 \%)$ and mild urticaria (26.4\%); even $13,9 \%$ of the participants reported no itch and bump. This suggested that AHT was effective in reducing UAS7 in urticaria patients from 30.77 on week 1 to 4.12 on week $10 \mathrm{p}$ value $=0,000)$. You et al. (2015) also reported the same result, suggesting that AHT is effective for severe CSU treatment. ${ }^{9}$ Kitsioulis et al. (2017) reported significant UAS7 improvements in AHT in chronic spontaneous urticaria from 34.26 to 12.52 . Kitsoulis et al. also reported that 10 out of 19 patients have improved by $\geq$ 28 points. $^{6}$

This study result showed an improvement in DLQI from 21.66 on week 1 to 2.51 on week 10 (p value $=0.000)$. Kitsioulis et al. (2017) also reported a significant improvement in DLQI score from 11.63 to 3.47 .6

The mechanism of action of AHT in chronic urticaria patients is still not completely clear. You et al. (2015) argued that AHT can sensitize patients to triggering factors including autoantibodies. ${ }^{8} \mathrm{~A}$ theory also stated that patients treated with AHT will experience a shift in the pattern of immune response from Th2 to Th1 patterns. This was based on research by Piconi et al. (2002) and Staubach (2006) regarding the effectiveness of autohemotherapy in autologous serum skin test (ASST)-positive patients. ${ }^{10,11}$ In chronic urticaria, AHT is also thought to cause desensitization due to repeated administration of histamine-releasing factor (HRF). ${ }^{10}$ Blood is collected and injected back into the tissue or muscles. This will then stimulate the immune system by activating and increasing the number of macrophages from $5 \%$ to $22 \%$ in 5 days. In line with this, previous research showed that the mechanism of AHT involves antigens in the blood which stimulates the production of antibodies as they are injected into the tissue to form the body's defense response to the antigen. ${ }^{12}$

Only $2.8 \%$ of patients had bruise at blood collection site, and $1.4 \%$ of them had bruises at the injection site. Bruises can be reduced by proper blood sampling and intramuscular injection techniques.
Blood drawn from v. mediana cubiti, with the needle position 45 degrees facing up. This allowed the blood to flow into the needle for blood collection. ${ }^{13}$

Only $1.4 \%$ of respondents experience an increase in body temperature. Further examination revealed that the patient had a respiratory infection. This concluded that the increase in body temperature was not related with AHT.

As many as $19.4 \%$ of study participants had flares that occurred in the $5^{\text {th }}-6^{\text {th }}$ week. Immune exhaustion due to continuous antigen exposure was thought to cause this. T cells do not always work optimally under conditions of antigen persistence but can be less responsive with regard to memory $\mathrm{T}$ cell populations. This happened temporarily. ${ }^{14}$

No significant adverse events were found, and this was similar to previous studies. ${ }^{7,10}$ This study concluded that AHT was safe and effective, and it is simple, safe, inexpensive alternative therapy for chronic urticaria.

The limitation of this study was there was no comparison group due to logistical, financial constraints. Besides, the sample size was small. In addition, it was possible that antihistamines affected the treatment outcome. This concludes that autohemotherapy can serve as an option for chronic urticaria treatment due to its effectiveness.

There was a significant decrease in UAS7 and DLQI in chronic urticaria patients after receiving AHT therapy for 10 weeks. This research supports the basis for the selection of AHT as a therapy in chronic urticaria. No severe side effects observed in the study participants. We suggest future research on AHT with bigger sample size and gold standard therapy as comparison.

\section{REFERENCE}

1. Maurer M. Urticaria and angioedema. Chem Immunol Allergy 2014;100:101-4.

2. Sánchez-Borges $\mathrm{M}$, Asero R, Ansotegui IJ, Baiardini I, Bernstein JA, Canonica GW, et al. Diagnosis and treatment of urticaria and angioedema. World Allergy Organ J 2012;5(11):125-47.

3. Zuberbier T, Aberer W, Asero R, Abdul Latiff AH, Baker D, Ballmer-Weber B, et al. The EAACI/GA ${ }^{2} \mathrm{LEN} / \mathrm{EDF} / \mathrm{WAO}$ guideline for the definition, classification, diagnosis and management of urticaria. Allergy Eur J Allergy Clin Immunol 2018;73(7):1393-414.

4. Hide M, Takahagi S, Hiragun T. Urticaria and angioedema. In: Kang S, Amagai M, Bruckner AL, Enk AH, Margolis DJ, McMichael AJ, et al., editors. Fitzpatrick's Dermatology. 9th ed. New 
York: McGraw-Hill Humanities/Social Sciences/Languages; 2019. p. 685-709.

5. Brewer DD. A systematic review of autohemotherapy as a treatment for urticaria and eczema. Cureus 2014;6(12):1-19.

6. Kitsioulis N, Xepapadaki P, Roussaki-Schulze A, Papadopoulos N, Zafiriou E. Effectiveness of autologous whole-blood injections in patients with refractory chronic spontaneous urticaria. Int Arch Allergy Immunol 2017;172:161-6.

7. Kocaturk E, Aktas S, Turkoglu Z, Kavala M, Zindanci I, Koc M. Autologous whole blood and autologous serum injections are equally effective as placebo injections in reducing disease activity in patients with chronic spontaneous urticaria: a placebo controlled, randomized, single-blind study. J Dermatol Treat 2012;25:465-71.

8. You H, Cho H, Kim W, Mun J, Song M, Kim H, et al. Autologous whole blood injection for the treatment of antihistamine-resistant chronic spontaneous urticaria. Ann Dermatol 2015;27(6):784.

9. Nopriyati, Thaha MA, Tjekyan S. Hubungan autologous serum skin test (ASST) dengan keparahan klinis urtikaria kronik idiopatik di RSUP Dr. Moh Hoesin Palembang. Makara 2008;12(1):27-35.

10. Staubach P, Onnen K, Vonend A, Metz M, Siebenhaar F, Tschentscher I, et al. Autologous whole blood injections to patients with chronic urticaria and a positive autologous serum skin test : A placebo-controlled trial. Dermatol 2006;212: 150-9.

11. Piconi S, Trabattoni D, Iemoli E, Fusi M, Villa M, Milazzo F, et al. Chronic idiopathic urticaria. Int Arch Allergy Immunol 2002;128:59-66.

12. Rivitti EA. From desensitizing hemotherapy of the past to the current immunomodulating therapy with high doses of intravenous imunomoduladora atual por Imunoglobulina Endovenosa. Brazilian Dermatol Ann 2005;80(6):643-50.

13. World Health Organization. Blood donor counselling. World Health Organization, editor. Blood Donor Counseling. $1^{\text {st }}$ ed. Geneva: World Health Organization, WHO; 2014. p. 3-4.

14. Yi JS, Cox MA, Zajac AJ. T-cell exhaustion: characteristics, causes and conversion. Immunology 2010;2:474-81. 